\title{
New Microporous Polymer Electrolyte Based on Polysiloxane Grafted with Imidazolium Iodide Moieties for DSSC
}

\author{
Yan Yang, Jie Tao, Xin Jin, and Qi Qin \\ College of Material Science and Technology, Nanjing University of Aeronautics and Astronautics, Nanjing 210016, China \\ Correspondence should be addressed to Jie Tao, taojie@nuaa.edu.cn
}

Received 26 May 2010; Accepted 16 July 2010

Academic Editor: Canan Varlikli

Copyright ( $) 2011$ Yan Yang et al. This is an open access article distributed under the Creative Commons Attribution License, which permits unrestricted use, distribution, and reproduction in any medium, provided the original work is properly cited.

Two types of polysiloxane grafted with different ratio of imidazolium iodide moieties ( $\left.\mathrm{IL}-\mathrm{SiO}_{2}\right)$ have been synthesized to develop a micro-porous polymer electrolyte for quasi-solid-state dye-sensitized solar cells. The samples were characterized by ${ }^{1} \mathrm{HNMR}$, FT-IR spectrum, XRD, TEM and SEM, respectively. Moreover, the ionic conductivity of the electrolytes was measured by electrochemical workstation. Nanostructured polysiloxane containing imidazolium iodide showed excellent compatibility with organic solvent and polymer matrix for its ionic liquid characteristics. Increasing the proportion of imidazolium iodide moieties in polysiloxane improved the electrochemical behavior of the gel polymer electrolyte. A dye-sensitized solar cell with gel polymer electrolyte yielded an open-circuit voltage of $0.70 \mathrm{~V}$, short-circuit current of $11.19 \mathrm{~mA} \mathrm{~cm}^{-2}$, and the conversion efficiency of $3.61 \%$ at 1 sun illumination.

\section{Introduction}

In recent years, dye-sensitized solar cells (DSSCs) have received much attention because of their high efficiency and low cost [1]. Although liquid electrolyte dye-sensitized solar cells reach power conversion efficiencies of over $11 \%$ [2], the main problem is that the liquid electrolytes limit device stability because the liquid may evaporate when the cell is imperfectly sealed, and more generally, the permeation of water or oxygen molecules and their reaction with the electrolytes may worsen cell performance. To solve these problems, alternative robust sealing methods, replacement of the volatile solvents with ionic liquid $[3,4]$, organic and inorganic hole-transport materials $[5,6]$, nanocomposites $[7,8]$, and solid and quasi-solid state polymer electrolytes $[9,10]$ have been attempted.

Polysiloxanes have highly flexible backbone, with the barrier to bond rotation being only $0.8 \mathrm{~kJ} \mathrm{~mol}^{-1}$, as well as very low $\operatorname{Tg}\left(-123^{\circ} \mathrm{C}\right)$ and high free volumes, therefore polysiloxanes-based electrolytes have received much attention. Ren et al. reported a gel network polymer electrolyte based on polysiloxane with internal plasticizing PEO chains applied in solid-state DSSCs. Ethylene carbonate (EC)/propylene carbonate (PC) and $\mathrm{LiI} / \mathrm{I}_{2}$ were added as liquid plasticizer to improve the performance. The cells showed open circuit voltage of $0.69 \mathrm{~V}$ and short-circuit current density of $1.7 \mathrm{~mA} / \mathrm{cm}^{2}$ under $28 \mathrm{~mW} / \mathrm{cm}^{2}$ white light illumination. The energy conversion efficiencies and fill factors of the cells were 2.9\% [11]. And then a series of novel quaternary ammonium iodides, the polysiloxanes with oligo (oxyethylene) side chains and quaternary ammonium groups, was synthesized in their laboratory. Polymer electrolytes prepared by blending these quaternary ammonium iodides with PEO or PAN were successfully used in fabricating quasi-solid-state DSSCs $[12,13]$. Lianos and coworkers have used a nanocomposite silica-based gel with an organic subphase containing propylene carbonate, 1-methyl3-propylimidazolium iodide, and Triton as surfactant. When applied as electrolyte in DSSCs, it gave a maximum efficiency of $5.4 \%$ [14]. The same group achieved an efficiency of $5 \%-6 \%$ with a nanocomposite organic-inorganic sol-gel electrolyte which incorporated a hydrolysable alkoxysilane derivative [15].

However, the polysiloxane-based polymer electrolytes are gums at room temperature rather than solids, and recent efforts have been focused on the design and synthesis of polymers with both high ion transport and good dimensional stability. In our previous paper, a microporous polymer 


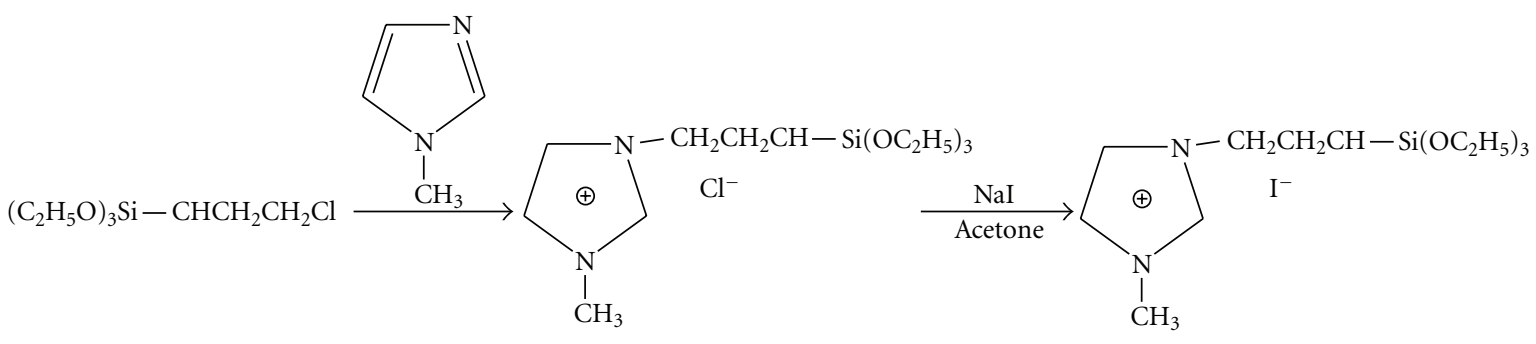

SCHeme 1: Synthesis of TESPIm ${ }^{+} \mathrm{I}^{-}$.

electrolyte based on PVDF and ionic liquid functionalized $\mathrm{SiO}_{2}\left(\mathrm{IL}-\mathrm{SiO}_{2}\right)$ for DSSCs was reported [16]. The selfstanding porous film owns high ambient conductivity and good dimensional stability. And $\mathrm{IL}_{-} \mathrm{SiO}_{2}$ improved the compatibility with liquid electrolyte and polymer matrix for its ionic liquid characteristics. In this paper, we extend our research to investigate the effects of proportion of imidazolium iodide moieties on the conductivities and the cell performances.

\section{Experimental}

\subsection{Polysiloxane Functionalization}

2.1.1. Synthesis of Imidazolium Iodide Containing Triethoxysilane Group. The imidazolium iodide type ionic liquid, namely, TESPIm ${ }^{+}{ }^{-}$was synthesized with Teflonlined stainless autoclaves under solvent-free conditions (seeing Scheme 1). The mixture of 1-methylimidazolium (75.0 $\mathrm{mmol})$ and 3-chloropropyltriethoxysilane $(80.0 \mathrm{mmol})$ was placed in a $50 \mathrm{~mL}$ Teflonline stainless steel autoclave, and then was heated in an oven at $120^{\circ} \mathrm{C}$ for 24 hours. The resulting yellow liquid was washed several times with ethyl ether and then dried in a vacuum oven at $80^{\circ} \mathrm{C}$ for 24 hours as follows: ${ }^{1} \mathrm{HNMR}$ (DMSO-d6, 500 MHZ) $\delta: 0.51$ $(\mathrm{t}, 2 \mathrm{H}), 1.04-1.16(\mathrm{~m}, 9 \mathrm{H}), 1.82(\mathrm{~d}, 2 \mathrm{H}), 3.67-3.76(\mathrm{~m}, 6 \mathrm{H})$, $3.87(\mathrm{~s}, 3 \mathrm{H}), 4.14(\mathrm{t}, 2 \mathrm{H}), 7.77(\mathrm{~m}, 1 \mathrm{H}), 7.84(\mathrm{~m}, 1 \mathrm{H})$, and 9.25 $(\mathrm{s}, 1 \mathrm{H})$.

2.1.2. Synthesis of Polysiloxane Grafted with Imidazolium Iodide Moieties $\left(\mathrm{IL}^{-} \mathrm{SiO}_{2}\right)$. An amount of $\mathrm{TESPIm}^{+} \mathrm{I}^{-}$and tetraethoxysilane (TEOS) was mixed in ethanol. The molar ratios of TESPIm ${ }^{+} \mathrm{I}^{-} / \mathrm{TEOS}$ were $1 / 1,2 / 1$, respectively. $1 \mathrm{wt} . \%$ hydrochloric acid was then added under continuous stirring. The mixture was refluxed at $55^{\circ} \mathrm{C}$ for 6 hours and then dried via rotary evaporation to obtain yellow solid productions $\mathrm{IL}_{-} \mathrm{SiO}_{2}(1 / 1), \mathrm{IL}_{-} \mathrm{SiO}_{2}(2 / 1)$, respectively (seeing Scheme 2).

2.2. Preparation of Gel Polymer Electrolytes. The porous polymer membrane composed of poly(vinylidene fluoride) (PVDF, SOLEF 1015) and $\mathrm{IL}_{-} \mathrm{SiO}_{2}$ was synthesized by the phase inversion process. The dried polymer powders of PVDF and $\mathrm{IL}_{-} \mathrm{SiO}_{2}$ were dissolved in $\mathrm{N}, \mathrm{N}-$ dimethylformamide. The weight ratios of PVDF/(IL-SiO $\left.{ }_{2}\right)$ polymer mixtures were $9 / 1,8 / 2,7 / 3,6 / 4,5 / 5$, and $4 / 6$, respectively. An amount of propanetriol as nonsolvent was then added under continuous stirring at $60^{\circ} \mathrm{C}$ for 12 hours to form homogeneous hybrid. The resulting viscous mixture spread on a glass substrate was heated to $80^{\circ} \mathrm{C}$ for 24 hours to remove solvent and nonsolvent.

The formed films were immersed in ethanol to extract residual propanetriol. Finally, the dried polymer membranes were soaked in liquid electrolyte $\left(0.5 \mathrm{~mol} / 1 \mathrm{NaI}, 0.05 \mathrm{~mol} / 1 \mathrm{I}_{2}\right.$, $0.1 \mathrm{~mol} / \mathrm{l}$ 4-tert-butylpyrdine) in the binary organic solvents mixture propylene carbonate and ethylene carbonate with $4: 6(\mathrm{w} / \mathrm{w})$ for 12 hours to obtain the desired gel polymer electrolytes (GPEs). The thickness of the gel electrolyte was about $100 \mu \mathrm{m}$.

DSSCs Assembly. The $\mathrm{TiO}_{2}$ film based on self-aligned highly ordered $\mathrm{TiO}_{2}$ nanotube arrays was immerged in a $0.5 \mathrm{mMOL}$ ethanol solution of $c i s-\left[\left(\mathrm{dcbH}_{2}\right)_{2} \mathrm{Ru}(\mathrm{SCN})_{2}\right]$ (N719; Solaronix) for 24 hours to absorb the dye adequately [17]. A quasi-solid-state dye-sensitized solar cell was assembled by sandwiching a slice of gel polymer electrolyte between a dyesensitized $\mathrm{TiO}_{2}$ electrode and a platinum counter electrode (purchased from DYESOL). The two electrodes were clipped together with clamps. The active area of the cell was $0.25 \mathrm{~cm}^{2}$.

2.3. Measurements. ${ }^{1} \mathrm{HNMR}$ was recorded on a $500 \mathrm{MHz}$ spectrometer (BRUKER DRX500) using DMSO-d6 as solvent. The molecular weight of $\mathrm{IL}_{-} \mathrm{SiO}_{2}$ was recorded on GPC. The morphology of $\mathrm{IL}_{-} \mathrm{SiO}_{2}$ was analyzed by means of transmission electron microscopy (FEI Tecnai G2) with energy dispersive X-ray spectrometry (EDS). The X-ray diffraction (XRD) measurement was performed with a Bruker D8 diffractometer. The morphology of polymer membrane was characterized by scanning electron micrograph (Quanta200, FEI). The IR absorption spectra were taken using an attenuated total reflection Fourier transform infrared spectrometer (PerkinElmer1760) over the range from 600 to $4000 \mathrm{~cm}^{-1}$. $n$-butanol absorption technique was used to measure the porosity of the polymer membranes [18]. The electrolyte uptake was calculated by Uptake $=\left(W_{i}-W_{0}\right) / W_{0} \times 100 \%$, where $W_{i}$ and $W_{0}$ were the weight of the wet and dry membranes, respectively.

The measurement cell was made by sandwiching the GPE membrane between two $\mathrm{Pt}$ electrodes (Pt/electrolyte/Pt). The electrolyte resistance $R_{b}$ was measured by AC impedance using CHI660 electrochemical workstation. The ionic conductivity of the GPE $(\sigma)$ was calculated with the equation: $\sigma$ $=d / R_{b} S$, where $d$ is the thickness of electrolyte, $S$ is the area of electrolyte. 


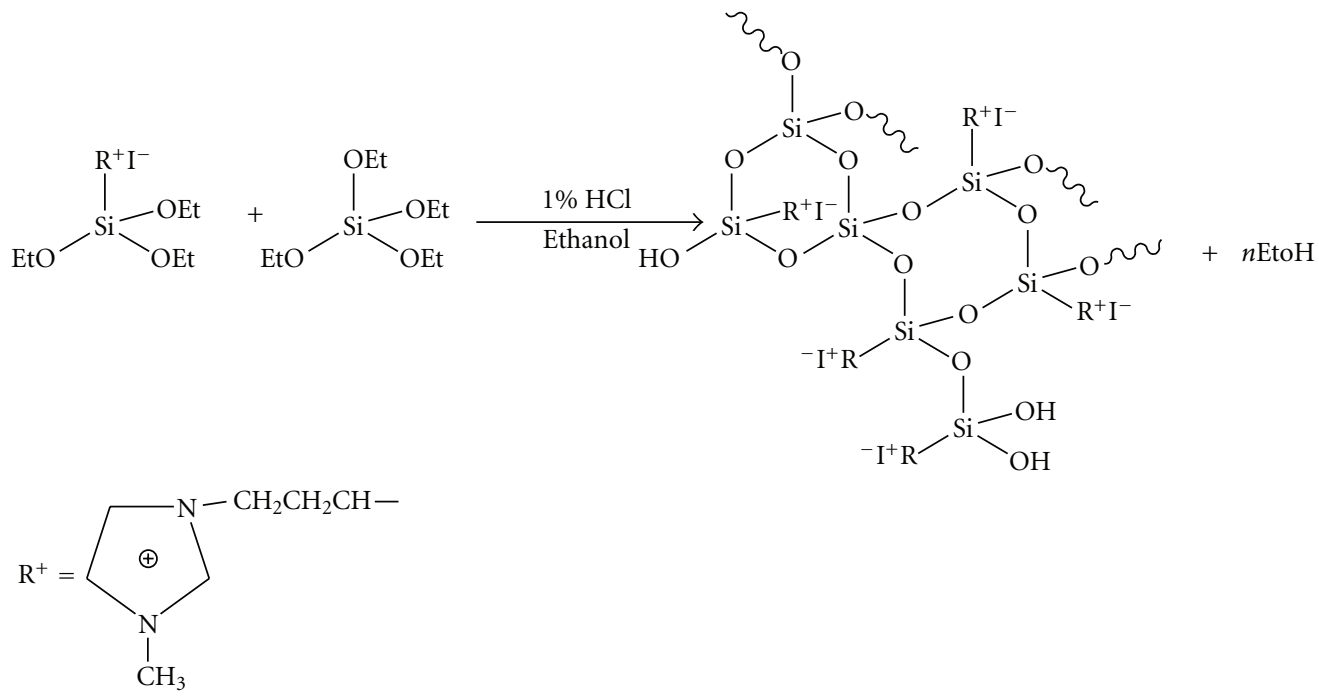

Scheme 2: Synthesis of IL-SiO ${ }_{2}$.

The steady-state voltammograms of GPE was performed to investigate the triiodide apparent diffusion coefficient $(D)$ in the electrolyte. $D=I_{\text {lim }} d / 2 n F C$, where $I_{\text {lim }}$ is limiting current density, $n$ is the electron number per molecule, $d$ is the thickness of gel electrolyte, $F$ is the Faraday constant, and $C$ is the bulk concentration of electroactive species [19].

Photocurrent-voltage characteristics of the DSSCs were obtained by a Keithley model 2400 digital source meter using an Oriel 91192 solar simulator equipped with AM 1.5 filter and intensity of $100 \mathrm{~mW} / \mathrm{cm}^{2}$. The fill factor (ff) and the conversion efficiency $(\eta)$ of the cell are calculated by the following equations: $f f=P_{\max } / I_{\mathrm{sc}} V_{\mathrm{oc}}=I_{\mathrm{mp}} V_{\mathrm{mp}} / I_{\mathrm{sc}} V_{\mathrm{oc}}$, $\eta=I_{\mathrm{mp}} V_{\mathrm{mp}} / P_{\mathrm{in}} \times 100 \%$, where $I_{\mathrm{sc}}$ is the short-circuit current density $\left(\mathrm{mA} \mathrm{cm}^{-2}\right), V_{\mathrm{oc}}$ is the open-circuit voltage $(\mathrm{V})$, and $P_{\text {in }}$ is the incident light power. $I_{\mathrm{mp}}\left(\mathrm{mA} \mathrm{cm} \mathrm{cm}^{-2}\right)$ and $V_{\mathrm{mp}}(\mathrm{V})$ are the current density and voltage in the $I-V$ curves, respectively, at the point of maximum power output.

\section{Results and Discussion}

3.1. Characterization of Polysiloxane Drafted with Imidazolium Iodide Moieties. Figure 1 shows FT-IR spectra of TESPIm ${ }^{+} \mathrm{I}^{-}$and two types of $\mathrm{IL}_{-} \mathrm{SiO}_{2}, \mathrm{IL}_{-}-\mathrm{SiO}_{2}(1 / 1)$, and IL-SiO $\mathrm{S}_{2}(2 / 1)$. The disappearance of the vibration band at around $960 \mathrm{~cm}^{-1}$ characteristic of SiOEt groups of the starting chemical and the presence of a strong vibration band from 1000 to $1200 \mathrm{~cm}^{-1}$, attributable to $\mathrm{Si}-\mathrm{O}-\mathrm{Si}$, in the FTIR spectrum of IL-SiO $\mathrm{S}_{2}$ confirms the formation of silica network [20]. Moreover, imidazolium iodide moieties contained in silica network is determined by the existence of sharp lines around 1570, 1467, corresponding to stretching vibration bands of imidazole ring. Also, the absorption peak at around $3400 \mathrm{~cm}^{-1}$ indicates the presence of silanols.

It can be recognized that the relative intensity of the peaks corresponding to imidazole ring increases with increasing the molar ratios of TESPIm ${ }^{+} \mathrm{I}^{-} / \mathrm{TEOS}$, and at mean time

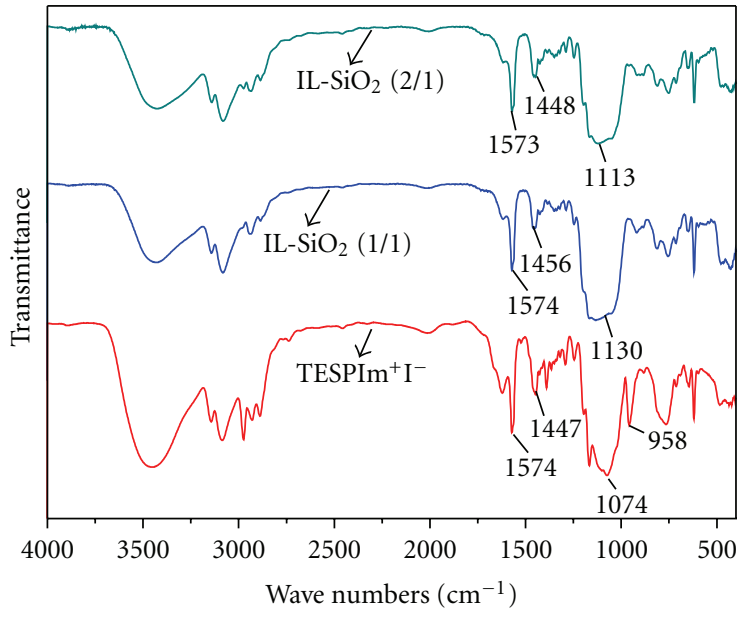

Figure 1: FT-IR spectra of TESPIm ${ }^{+} \mathrm{I}^{-}$and $\mathrm{IL}_{-} \mathrm{SiO}_{2}$.

the relative intensity of the peaks corresponding to Si-O$\mathrm{Si}$ decreases. It can be considered that the proportion of imidazolium iodide moieties in IL-SiO $2(2 / 1)$ is higher than in $\mathrm{IL}_{-} \mathrm{SiO}_{2}(1 / 1)$, but the inorganic contents in $\mathrm{IL}-\mathrm{SiO}_{2}(2 / 1)$ are lower than in $\mathrm{IL}-\mathrm{SiO}_{2}(1 / 1)$.

Both types of $\mathrm{IL}_{-} \mathrm{SiO}_{2}$ can be dispersed to nanosized particles with no obvious agglomeration as clearly shown by the TEM image of Figure 2. It can be thought that the $\mathrm{IL}-\mathrm{SiO}_{2}$, made by the sol \pm gel process by utilizing TEOS and TESPIm ${ }^{+} \mathrm{I}^{-}$, is composed of covalently linked $\mathrm{SiO}_{2}$ and imidazolium iodide moieties networks well mixed on the nanoscale. IL-SiO ${ }_{2}(1 / 1)$ has narrow particle size distribution and a mean particle size of $200 \mathrm{~nm}$ (seeing Figure 2(a)). IL-SiO 2 (2/1) is evenly distributed about $10 \mathrm{~nm}$ in diameters, with very few big size particles about $100 \mathrm{~nm}$ in diameters (seeing Figure 2(b)). It is possible that in 


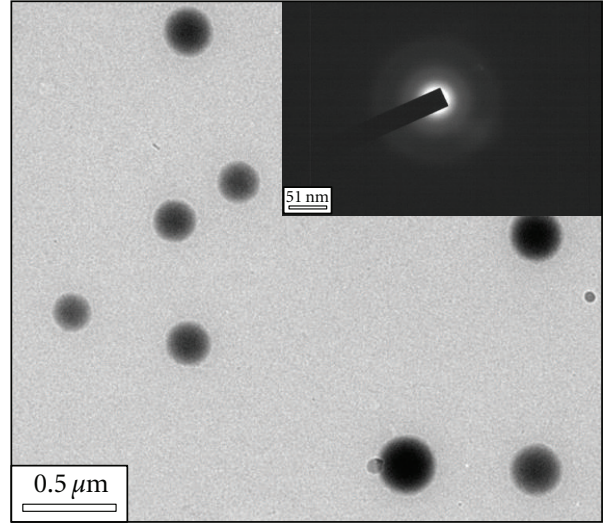

(a)

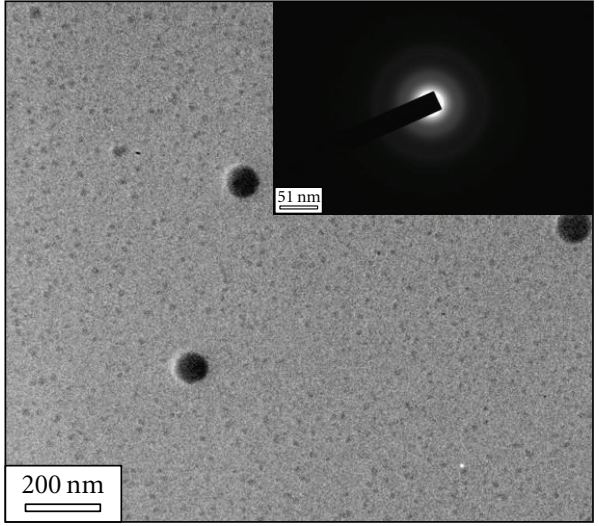

(b)

Figure 2: TEM images of IL-SiO ${ }_{2}$. (a) $\mathrm{IL}_{-} \mathrm{SiO}_{2}(1 / 1)$, (b) $\mathrm{IL}_{-} \mathrm{SiO}_{2}(2 / 1)$.

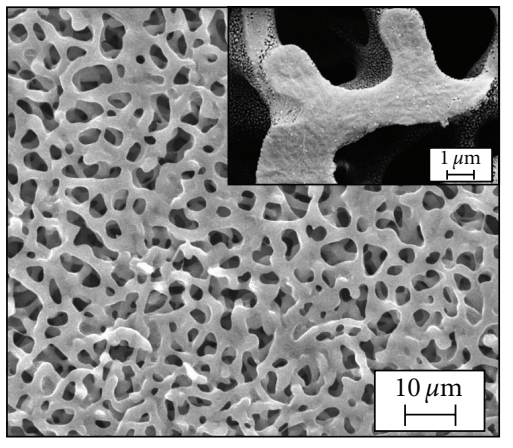

(a)

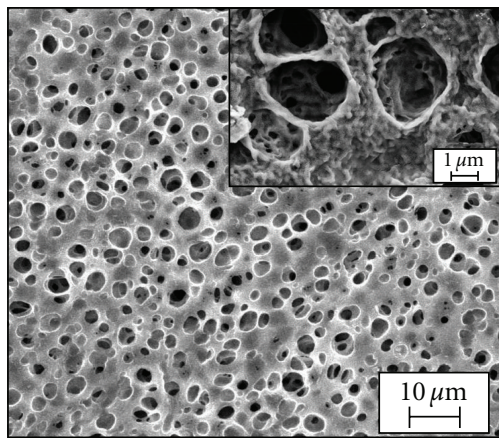

(d)

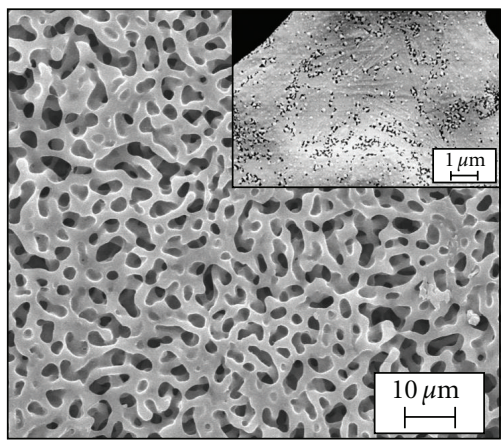

(b)

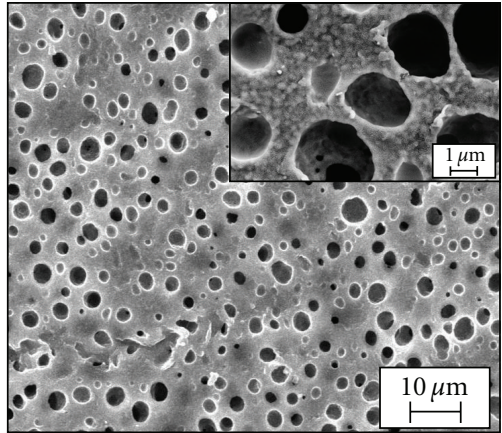

(e)

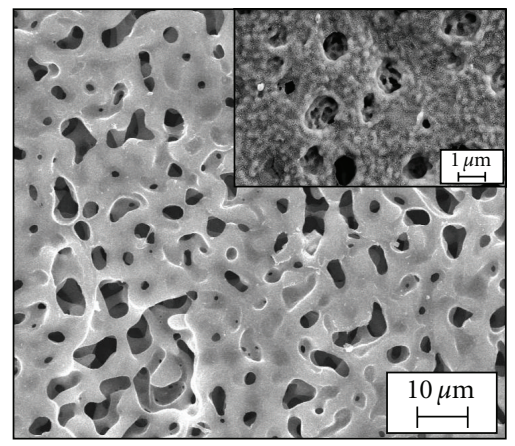

(c)

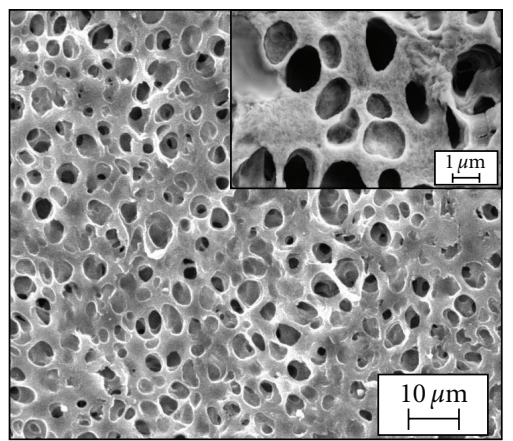

(f)

Figure 3: SEM images of polymer membranes PVDF/IL-SiO $\mathrm{S}_{2}(1 / 1)$. (a) the weight ratio of PVDF/IL-SiO 2 is $9 / 1$. (b) the weight ratio of $\mathrm{PVDF} / \mathrm{IL}-\mathrm{SiO}_{2}$ is $8 / 2$. (c) the weight ratio of $\mathrm{PVDF} / \mathrm{IL}-\mathrm{SiO}_{2}$ is $7 / 3$. (d) the weight ratio of $\mathrm{PVDF} / \mathrm{IL}-\mathrm{SiO}_{2}$ is $6 / 4$. (e) the weight ratio of $\mathrm{PVDF} / \mathrm{IL}-\mathrm{SiO}_{2}$ is $5 / 5$. (f) the weight ratio of $\mathrm{PVDF} / \mathrm{IL}-\mathrm{SiO}_{2}$ is $4 / 6$.

addition to the TESPIm ${ }^{+} \mathrm{I}^{-}$reacting with TEOS, selfcondensation may also occur, leading to the formation of dimers, trimers, and higher oligomers of TESPIm ${ }^{+} \mathrm{I}^{-}$or TEOS. And it is more likely that self-condensation occurs between TEOS for their higher activity than TESPIm ${ }^{+} \mathrm{I}^{-}$, so the size of particles increases with increasing the molar ratios of TESPIm ${ }^{+} \mathrm{I}^{-} /$TEOS. In addition, it can be drawn from electron diffraction analysis that both types of $\mathrm{IL}_{-} \mathrm{SiO}_{2}$ are amorphous material.
The molecular weights (Mws) and polydispersity index (PDI) of the $\mathrm{IL}^{-\mathrm{SiO}_{2}}$ were determined using GPC (seeing Table 1). There is no great difference between two types of $\mathrm{IL}-\mathrm{SiO}_{2}$. The molecular weight of $\mathrm{IL}-\mathrm{SiO}_{2}$ $(1 / 1)$ is a little bigger than that of $\mathrm{IL}_{-} \mathrm{SiO}_{2}(2 / 1)$. It is believed that more imidazolium iodide moieties of TESPIm ${ }^{+} \mathrm{I}^{-}$may impede the polycondensation of siloxane and, thus, hold back the growth of molecular chains. 


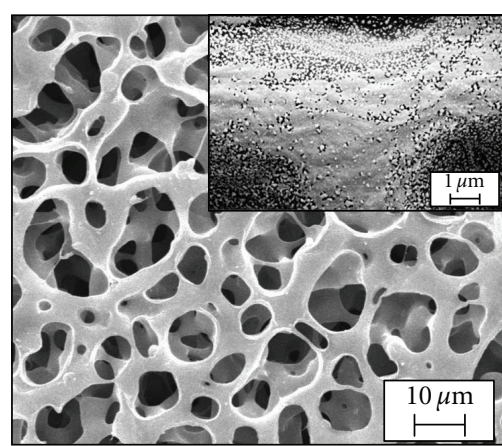

(a)

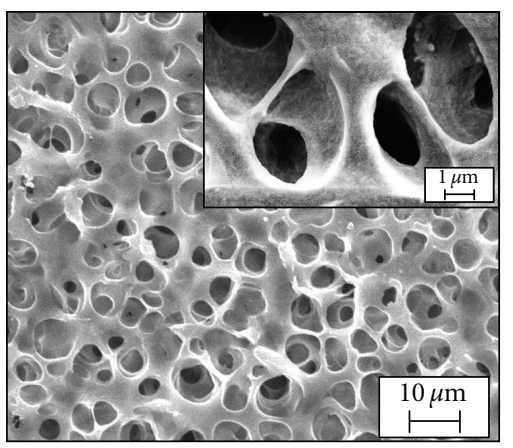

(d)

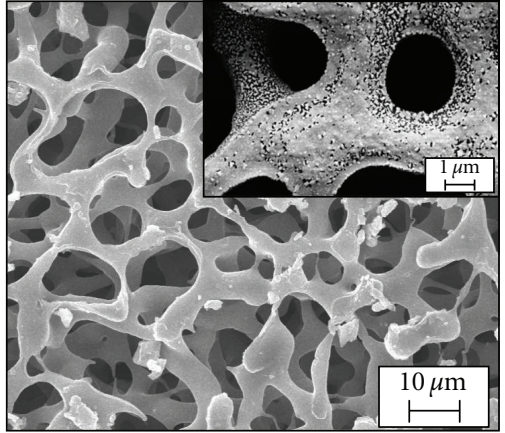

(b)

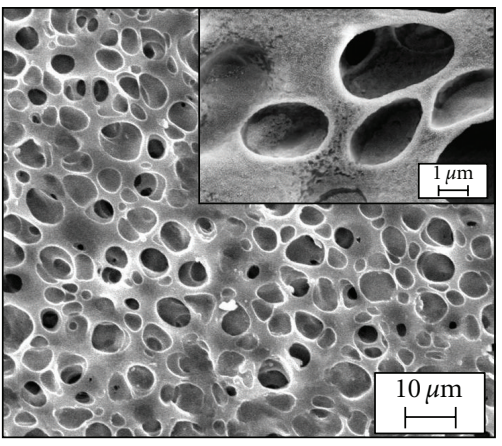

(e)

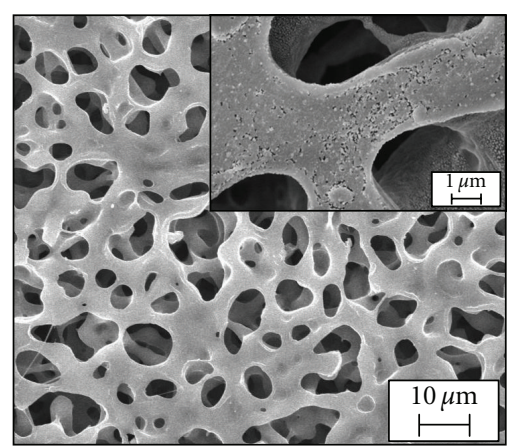

(c)

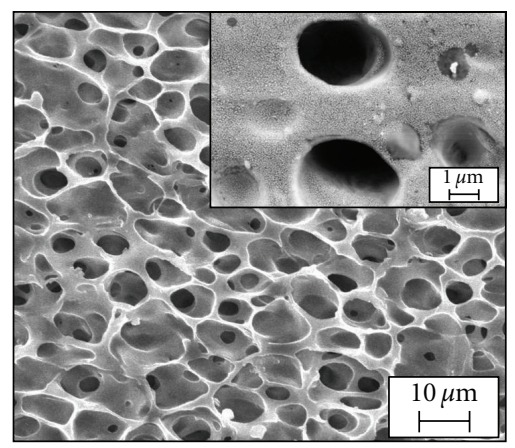

(f)

FIgURE 4: SEM images of polymer membranes PVDF/IL-SiO 2 (2/1). (a) the weight ratio of PVDF/IL-SiO 2 is $9 / 1$. (b) the weight ratio of $\mathrm{PVDF} / \mathrm{IL}-\mathrm{SiO}_{2}$ is $8 / 2$. (c) the weight ratio of $\mathrm{PVDF} / \mathrm{IL}-\mathrm{SiO}_{2}$ is $7 / 3$. (d) the weight ratio of $\mathrm{PVDF} / \mathrm{IL}-\mathrm{SiO}_{2}$ is $6 / 4$. (e) the weight ratio of $\mathrm{PVDF} / \mathrm{IL}-\mathrm{SiO}_{2}$ is $5 / 5$. (f) the weight ratio of $\mathrm{PVDF} / \mathrm{IL}-\mathrm{SiO}_{2}$ is $4 / 6$.
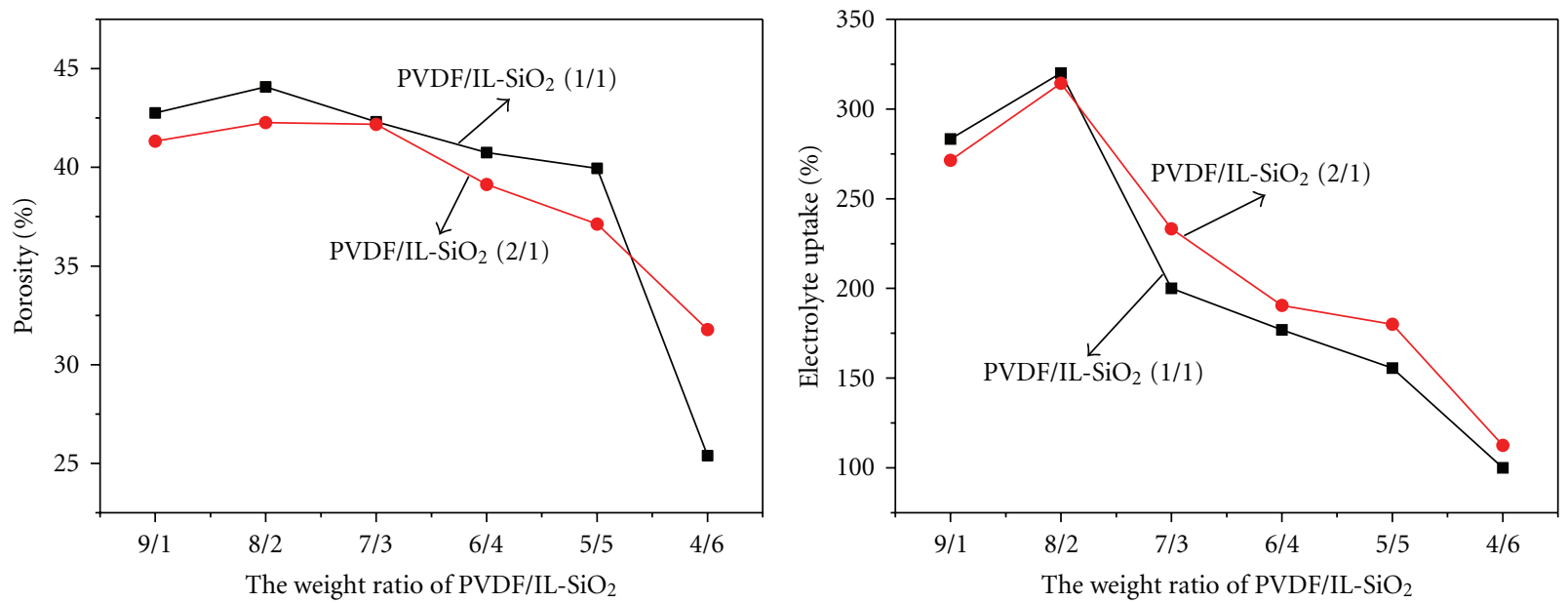

FIGURE 5: Porosity and electrolyte uptake of polymer membranes.

TABLE 1: The molecular weights of IL-SiO 2 .

\begin{tabular}{|c|c|c|c|}
\hline & $\begin{array}{l}\text { The molar ratios of } \\
\text { TESPIm }^{+} \mathrm{I}^{-} / \text {TEOS }\end{array}$ & $\begin{array}{c}\text { Mw } \\
\text { (Daltons) }\end{array}$ & Polydispersity \\
\hline $\mathrm{IL}-S i O_{2}(1 / 1)$ & $1: 1$ & 8311 & 1.009253 \\
\hline $\mathrm{IL}-S i O_{2}(2 / 1)$ & $2: 1$ & 8104 & 1.009567 \\
\hline
\end{tabular}

3.2. Performances of Microporous Polymer Membranes. The surface of microporous polymer membranes with different weight ratios of PVDF/IL-SiO ${ }_{2}(1 / 1)$ and $\mathrm{PVDF} / \mathrm{IL}-\mathrm{SiO}_{2}$ $(2 / 1)$ was observed by SEM (seeing Figures 3 and 4$)$.

The incorporation of IL-SiO 2 component into the microporous polymer matrix changed significantly the morphology. The membranes produced with low content $\mathrm{IL}-\mathrm{SiO}_{2}$ display regular porous structure (seeing Figures 3(a) and 3(b) and Figures 4(a) and 4(b)). The pore size of PVDF/IL-SiO $(2 / 1)$ membranes seems larger than that of PVDF/IL$\mathrm{SiO}_{2}(1 / 1)$. The interior of the membrane has a uniform porous structure as well as the exterior. This indicates that 

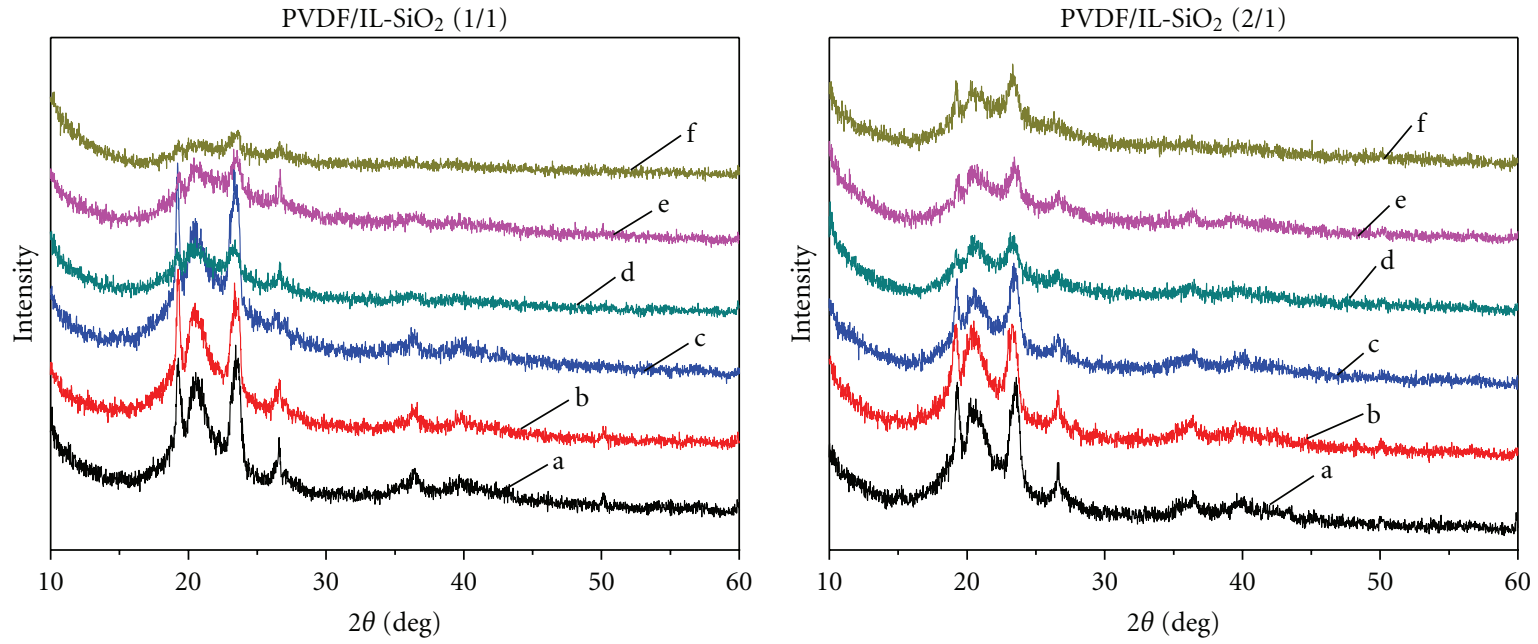

FIGURE 6: XRD patterns for PVDF/IL-SiO 2 polymer membranes. (a) PVDF/IL-SiO 2 ( $9: 1$ by weight). (b) PVDF/IL-SiO 2 ( $8: 2$ by weight). (c) PVDF/IL-SiO 2 ( $7: 3$ by weight). (d) PVDF/IL-SiO 2 ( $6: 4$ by weight). (e) PVDF/IL-SiO 2 ( $5: 5$ by weight). (f) PVDF/IL-SiO 2 ( $4: 6$ by weight).
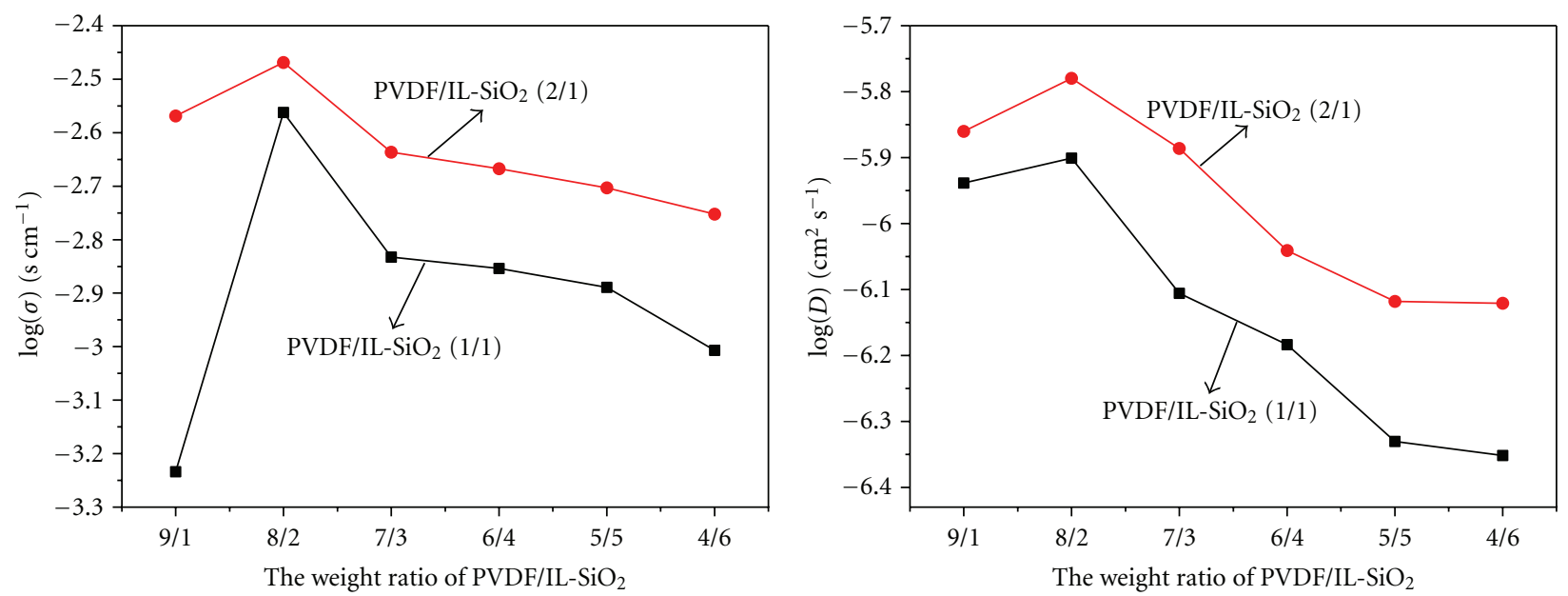

FIGURE 7: The ionic conductivity $(\sigma)$ and the apparent diffusion coefficient of triiodide $(D)$ of GPEs.

the cellular pores are all open with extensive pore-pore interconnections. But the size of the pores decreases with the increasing of the amount of $\mathrm{IL}_{-} \mathrm{SiO}_{2}$. Meanwhile, the connectivity of porous structure becomes poor, appearing more closed pores (seeing Figures 3(c)-3(f) and Figures $4(\mathrm{c})-4(\mathrm{f}))$.

It also can be seen that IL-SiO $\mathrm{S}_{2}$ are dispersed well on the membrane surface when the weight ratio of PVDF/IL$\mathrm{SiO}_{2}$ is low. The imidazolium iodide moieties linked on $\mathrm{SiO}_{2}$ are beneficial to prevent nanoparticle aggregation owing to the increase of distances between $\mathrm{SiO}_{2}$. To PVDF/IL-SiO (1/1) membrane, it is clear that residual silanol continue, to condensate forming more and bigger irregular particles when increasing the amount of $\mathrm{IL}_{-} \mathrm{SiO}_{2}$ (seeing Figures 3(c)-3(f)). But no obvious big particles are observed in PVDF/IL-SiO $(2 / 1)$ membranes. We have reasons to think that the higher proportion of imidazolium iodide moieties in $\mathrm{IL}^{-\mathrm{SiO}_{2}}(2 / 1)$ improved the particle dispersibility.
Figure 5 shows the porosity and electrolyte uptake of membranes with different polymer composition. The maximum of the porosity is observed when the weight ratio of $\mathrm{PVDF} / \mathrm{IL}-\mathrm{SiO}_{2}$ polymer is $8 / 2$. The tendency of the electrolyte uptake is similar to that of the porosity. It is notable that the porosity of PVDF/IL- $\mathrm{SiO}_{2}$ (1/1) membranes is greater than PVDF/IL- $\mathrm{SiO}_{2}(2 / 1)$ membranes, but the change law of electrolyte uptake is opposite. It can be thought that imidazolium iodide moieties grafted on polysiloxane are hopeful to efficient uptake of the liquid electrolyte.

The XRD characterization of pure $\mathrm{IL}-\mathrm{SiO}_{2}$ and the PVDF/IL-SiO ${ }_{2}$ polymer membranes are shown in Figure 6. There is a decrease in the relative intensity of the apparent peaks corresponding to polymer membrane with increasing $\mathrm{IL}-\mathrm{SiO}_{2}$ concentrations. This fact indicates that the crystallinity of PVDF can be reduced with the addition of $\mathrm{IL}-\mathrm{SiO}_{2}$. The hydrogen bond formation of remained silanols and the hydrolyzed silane prevents the polymer 


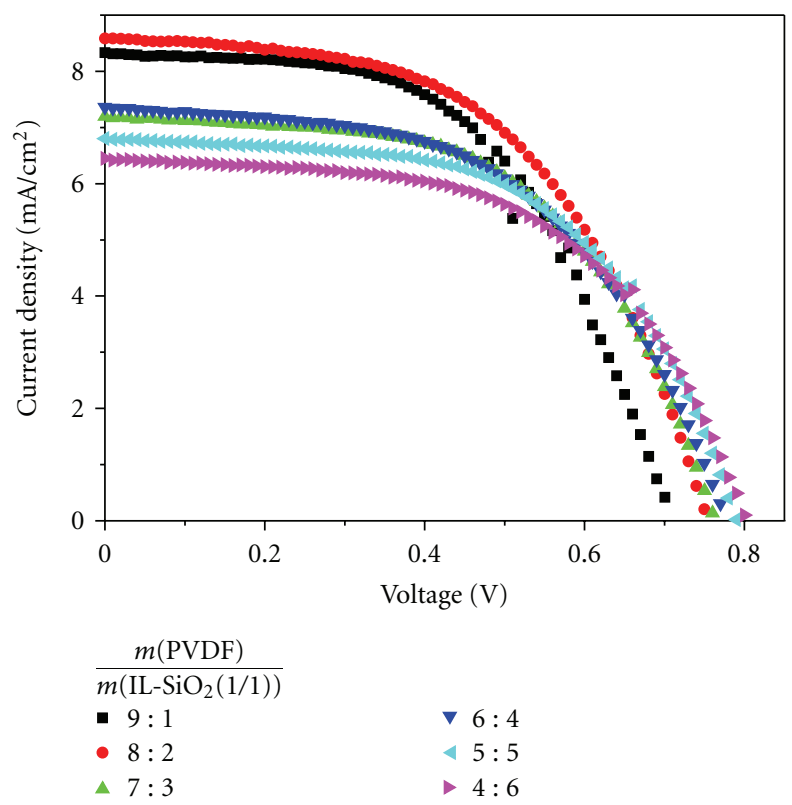

Figure 8: I-V curves of DSSCs with PVDF/IL-SiO 2 (1/1) GPEs.

chains to recrystallize [21]. Moreover, it can be seen that the relative intensity of the apparent peaks of PVDF/IL$\mathrm{SiO}_{2}(2 / 1)$ membranes is lower than that of PVDF/IL-SiO $(1 / 1)$ membranes. It means that the polysiloxane grafted with more imidazolium iodide moieties is propitious to reduce crystallinity of PVDF.

3.3. Ionic Conductivity and Triiodide Diffusion Coefficients of GPEs. EIS was used to characterize the electrochemical behavior of the gel polymer electrolyte. The ionic conductivity of the GPEs $(\sigma)$ and the triiodide apparent diffusion coefficient $(D)$ are summarized, respectively, in Figure 7.

IL-SiO $\mathrm{S}_{2}$ containing imidazolium iodide moieties show excellent compatibility with organic solvent or plasticizers, which is beneficial to form gel polymer electrolyte. Meanwhile, the crystallinity of the membrane is reduced with increasing $\mathrm{IL}-\mathrm{SiO}_{2}$ content as confirmed by XRD analysis. These favorable properties of $\mathrm{IL}-\mathrm{SiO}_{2}$ improve the conductivity of GPEs. But on the other hand, the porosity of the membrane decreases with increasing IL-SiO ${ }_{2}$ content, leading to the drop of the conductivity of GPEs. As a result, the gel polymer electrolyte shows the highest $\sigma$ and $D$ when the weight ratio of $\mathrm{PVDF} / \mathrm{IL}-\mathrm{SiO}_{2}$ polymer is $8 / 2$ and then decreased.

The greatest value $\sigma$ and $D$ obtained is $3.40 \times 10^{-3}$ and $1.66 \times 10^{-6}$ of $\mathrm{PVDF} / \mathrm{IL}-\mathrm{SiO}_{2}(2 / 1)$ system. Increasing the proportion of imidazolium iodide moieties in polysiloxane effectively improves the ionic conductivity and triiodide diffusion coefficients of GPEs for lower crystallinity and higher electrolyte uptake.

3.4. Photovoltaic Performance. The photocurrent performances for dye-sensitized solar cell with different electrolytes (A to F) were tested. The gel polymer electrolyte used in cell

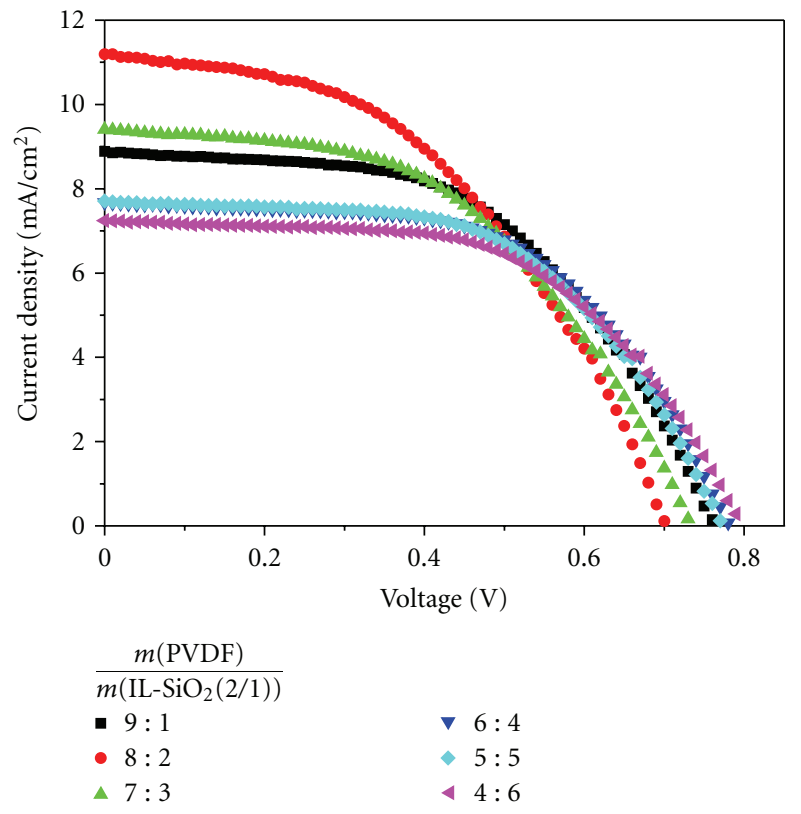

Figure 9: I-V curves of DSSCs with PVDF/IL-SiO 2 (2/1) GPEs.

TABLE 2: Photovoltaic performances of DSSCs with PVDF/IL-SiO ${ }_{2}$ (1/1) GPEs.

\begin{tabular}{lcccc}
\hline Cell & $V_{\mathrm{oc}}$ & $I_{\mathrm{sc}} / \mathrm{mA} \mathrm{cm}^{-2}$ & $f f$ & $\eta / \%$ \\
\hline A & 0.708 & 8.324 & 0.547 & 3.224 \\
B & 0.754 & 8.584 & 0.535 & 3.462 \\
C & 0.760 & 7.196 & 0.563 & 3.082 \\
D & 0.770 & 7.360 & 0.540 & 3.064 \\
E & 0.790 & 6.800 & 0.568 & 3.054 \\
F & 0.799 & 6.448 & 0.559 & 2.884 \\
\hline
\end{tabular}

TABle 3: Photovoltaic performances of DSSCs with PVDF/IL-SiO (2/1) GPEs.

\begin{tabular}{lcccc}
\hline Cell & $V_{\mathrm{oc}}$ & $I_{\mathrm{sc}} / \mathrm{mA} \mathrm{cm}^{-2}$ & $f f$ & $\eta / \%$ \\
\hline A & 0.763 & 8.888 & 0.527 & 3.576 \\
B & 0.702 & 11.192 & 0.459 & 3.611 \\
C & 0.733 & 9.408 & 0.497 & 3.429 \\
D & 0.782 & 7.676 & 0.572 & 3.432 \\
E & 0.772 & 7.708 & 0.564 & 3.359 \\
F & 0.796 & 7.240 & 0.567 & 2.272 \\
\hline
\end{tabular}

A is $\mathrm{PVDF} / \mathrm{IL}-\mathrm{SiO}_{2}(9: 1 \mathrm{~m} / \mathrm{m})$; in cell $\mathrm{B}$ is $\mathrm{PVDF} / \mathrm{IL}-\mathrm{SiO}_{2}$ $(8: 2 \mathrm{~m} / \mathrm{m})$; in cell C is PVDF/IL-SiO $2(7: 3 \mathrm{~m} / \mathrm{m})$; in cell $\mathrm{D}$ is $\mathrm{PVDF} / \mathrm{IL}-\mathrm{SiO}_{2}(6: 4 \mathrm{~m} / \mathrm{m})$; in cell $\mathrm{E}$ is $\mathrm{PVDF} / \mathrm{IL}-\mathrm{SiO}_{2}$ $(5: 5 \mathrm{~m} / \mathrm{m})$; in cell $\mathrm{F}$ is PVDF/IL-SiO $2(4: 6 \mathrm{~m} / \mathrm{m})$. The I-V curves of DSSCs with PVDF/IL-SiO 2 (1/1) GPEs and DSSCs with PVDF/IL-SiO 2 (2/1) GPEs are shown in Figures 8 and 9, respectively. And cell parameters corresponding to these DSSCs are summarized in Tables 2 and 3 , respectively.

The addition of $\mathrm{IL}_{-} \mathrm{SiO}_{2}(2 / 1)$ brought a significant improvement of the short-circuit current $\left(I_{\mathrm{sc}}\right)$ and the cell efficiency $(\eta)$. It could be attributed to better nanoparticle 
dispersibility in polymer network of PVDF/IL-SiO 2 (2/1), which promotes the movement of free ions in a regular direction. At the microscopic level, it maintains a "liquid-" like structure, which is important for sufficient conductivity [22]. While the high density of network formed by Si-O-Si in $\mathrm{PVDF} / \mathrm{IL}-\mathrm{SiO}_{2}(2 / 1)$ might hinder the charge transfer thus reduce the cell performance.

The variable trend of $I_{\mathrm{sc}}$ and $\eta$ can also be recognized from the variation of the ionic conductivity of the GPEs $(\sigma)$ and the triiodide apparent diffusion coefficient $(D)$ as indicated in Figure 7. The diffusion of triiodide $(D)$ plays a major role in DSSC performance. The faster transportation speed of the triiodide leads to the faster reduction of $\mathrm{I}^{-}$, and the faster reduction of excited dye molecule [23]. PVDF/IL-SiO 2 (2/1) GPEs showed higher $\sigma$ and $D$ than PVDF/IL-SiO 2 (1/1) GPEs. As a result, the cell employing GPE of PVDF/IL-SiO ${ }_{2}(2 / 1)$ with the weight of $8 / 2$ showed preferable photovoltaic performances. However, due to the poor conductive property when too much $\mathrm{IL}_{-} \mathrm{SiO}_{2}$ added, the cells of both systems showed lower short-circuit current and lower energy conversion efficiency.

\section{Conclusions}

We have synthesized two types of polysiloxane grafted with different ration imidazolium iodide moieties, $\mathrm{IL}_{-} \mathrm{SiO}_{2}(1 / 1)$ and $\mathrm{IL}-\mathrm{SiO}_{2}(2 / 1)$, through the sol \pm gel method. A gel polymer electrolyte based on $\mathrm{PVDF} / \mathrm{IL}-\mathrm{SiO}_{2}$ was prepared by soaking a porous membrane in an organic electrolyte solution containing the $\mathrm{I}^{-} / \mathrm{I}_{3}^{-}$redox couple. IL- $\mathrm{SiO}_{2}(2 / 1)$ with higher proportion of imidazolium iodide moieties improved the compatibility with liquid electrolyte and polymer marix more effectively for its ionic liquid characteristics. The greatest value $\sigma$ and $D$ obtained is $3.40 \times 10^{-3} \mathrm{~S} \mathrm{~cm}^{-1}$ and $1.66 \times 10^{-6} \mathrm{~cm}^{2} \mathrm{~s}^{-1}$ of PVDF/IL-SiO $2(2 / 1)$ system. The electrolytes prepared using this new inorganic/organic polymer composite improved cell performance by increasing $I_{\text {sc }}$ presumably through creating specific pathways for ion transportation and better ion conductive performance. A dye-sensitized solar cell employing GPE of PVDF/IL-SiO $(2 / 1)(8: 2 \mathrm{~m} / \mathrm{m})$ yielded an open-circuit voltage of $0.702 \mathrm{~V}$, short-circuit current of $11.192 \mathrm{~mA} \mathrm{~cm}^{-2}$, and the conversion efficiency of $3.611 \%$ at 1 sun illumination. The optimization of many parameters for the electrode preparation and the cell assembling is under study and further improvement of the photovoltaic performance is expected in the near future.

\section{References}

[1] M. Grätzel, "Photoelectrochemical cells," Nature, vol. 414, no. 6861, pp. 338-344, 2001.

[2] M. K. Nazeeruddin, P. Péchy, T. Renouard et al., "Engineering of efficient panchromatic sensitizers for nanocrystalline $\mathrm{TiO}_{2}$ based solar cells," Journal of the American Chemical Society, vol. 123, no. 8, pp. 1613-1624, 2001.

[3] B. Xue, H. Wang, Y. Hu et al., "Highly efficient dye-sensitized solar cells using a composite electrolyte," Comptes Rendus Chimie, vol. 9, no. 5-6, pp. 627-630, 2006.
[4] C. Zafer, K. Ocakoglu, C. Ozsoy, and S. Icli, "Dicationic bisimidazolium molten salts for efficient dye sensitized solar cells: synthesis and photovoltaic properties," Electrochimica Acta, vol. 54, no. 24, pp. 5709-5714, 2009.

[5] J. Bandara and H. Weerasinghe, "Solid-state dye-sensitized solar cell with p-type $\mathrm{NiO}$ as a hole collector," Solar Energy Materials and Solar Cells, vol. 85, no. 3, pp. 385-390, 2005.

[6] J. Xia, N. Masaki, M. Lira-Cantu, Y. Kim, K. Jiang, and S. Yanagida, "Influence of doped anions on poly $(3,4-$ ethylenedioxythiophene) as hole conductors for iodine-free solid-state dye-sensitized solar cells," Journal of the American Chemical Society, vol. 130, no. 4, pp. 1258-1263, 2008.

[7] Z. Huo, S. Dai, K. Wang et al., "Nanocomposite gel electrolyte with large enhanced charge transport properties of an $\mathrm{I}_{3}-/ \mathrm{I}^{-}$ redox couple for quasi-solid-state dye-sensitized solar cells," Solar Energy Materials and Solar Cells, vol. 91, no. 20, pp. 1959-1965, 2007.

[8] K.-C. Huang, R. Vittal, and K.-C. Ho, "Effects of crown ethers in nanocomposite silica-gel electrolytes on the performance of quasi-solid-state dye-sensitized solar cells," Solar Energy Materials and Solar Cells, vol. 94, no. 4, pp. 675-679, 2009.

[9] Y. Kim, Y.-E. Sung, J.-B. Xia, M. Lira-Cantu, N. Masaki, and S. Yanagida, "Solid-state dye-sensitized $\mathrm{TiO}_{2}$ solar cells using poly(3,4-ethylenedioxythiophene) as substitutes of iodine/iodide electrolytes and noble metal catalysts on FTO counter electrodes," Journal of Photochemistry and Photobiology A, vol. 193, no. 2-3, pp. 77-80, 2008.

[10] P.-Y. Chen, C.-P. Lee, R. Vittal, and K.-C. Ho, "A quasi solid-state dye-sensitized solar cell containing binary ionic liquid and polyaniline-loaded carbon black," Journal of Power Sources, vol. 195, no. 12, pp. 3933-3938, 2010.

[11] Y. Ren, Z. Zhang, E. Gao, S. Fang, and S. Cai, "A dyesensitized nanoporous $\mathrm{TiO}_{2}$ photoelectrochemical cell with novel gel network polymer electrolyte," Journal of Applied Electrochemistry, vol. 31, no. 4, pp. 445-447, 2001.

[12] J. Kang, W. Li, X. Wang, Y. Lin, X. Xiao, and S. Fang, "Polymer electrolytes from PEO and novel quaternary ammonium iodides for dye-sensitized solar cells," Electrochimica Acta, vol. 48, no. 17, pp. 2487-2491, 2003.

[13] G. Wang, X. Zhou, M. Li et al., "Gel polymer electrolytes based on polyacrylonitrile and a novel quaternary ammonium salt for dye-sensitized solar cells," Materials Research Bulletin, vol. 39, no. 13, pp. 2113-2118, 2004.

[14] E. Stathatos, P. Lianos, S. M. Zakeeruddin, P. Liska, and M. Grätzel, "A quasi-solid-state dye-sensitized solar cell based on a sol-gel nanocomposite electrolyte containing ionic liquid," Chemistry of Materials, vol. 15, no. 9, pp. 1825-1829, 2003.

[15] E. Stathatos, P. Lianos, V. Jovanovski, and B. Orel, "Dyesensitized photoelectrochemical solar cells based on nanocomposite organic-inorganic materials," Journal of Photochemistry and Photobiology A, vol. 169, no. 1, pp. 57-61, 2005.

[16] Y. Yang, J. Tao, X. Jin, and Q. Qin, "Preparation and characterization of a micro-porous polymer electrolyte based on PVDF/ionic liquid functionalized $\mathrm{SiO}_{2}$ for dye-sensitized solar cell," under peer review.

[17] Z. G. Bao, J. Tao, L. Wang, and X.T. He, "Effect of highlyordered $\mathrm{TiO}_{2}$ nanotube arrays on photovoltaic performance of dye-sensitized solar cell (DSSC)," Electronic Components and Materials, vol. 29, no. 6, pp. 64-68, 2010.

[18] N. K. Chung, Y. D. Kwon, and D. Kim, "Thermal, mechanical, swelling, and electrochemical properties of poly(vinylidene fluoride)-co-hexafluoropropylene/poly(ethylene glycol) hybrid-type polymer electrolytes," Journal of Power Sources, vol. 124, no. 1, pp. 148-154, 2003. 
[19] A. G. Kontos, M. Fardis, M. I. Prodromidis et al., "Morphology, ionic diffusion and applicability of novel polymer gel electrolytes with LiI// $\mathrm{I}_{2}$, Physical Chemistry Chemical Physics, vol. 8, no. 6, pp. 767-776, 2006.

[20] U. Lavrenčič Štangar, N. Grošelj, B. Orel, and P. Colomban, "Structure of and interactions between P/SiWA keggin nanocrystals dispersed in an organically modified electrolyte membrane," Chemistry of Materials, vol. 12, no. 12, pp. 37453753, 2000.

[21] Y. Liu, J. Y. Lee, and L. Hong, "In situ preparation of poly(ethylene oxide) $-\mathrm{SiO}_{2}$ composite polymer electrolytes," Journal of Power Sources, vol. 129, no. 2, pp. 303-311, 2004.

[22] W. Xiang, Y. Zhou, X. Yin, X. Zhou, S. Fang, and Y. Lin, "In situ quaterizable oligo-organophosphazene electrolyte with modified nanocomposite $\mathrm{SiO}_{2}$ for all-solid-state dyesensitized solar cell," Electrochimica Acta, vol. 54, no. 17, pp. 4186-4191, 2009.

[23] M. Grätzel, "Mesoscopic solar cells for electricity and hydrogen production from sunlight," Chemistry Letters, vol. 34, no. 1, pp. 8-13, 2005. 


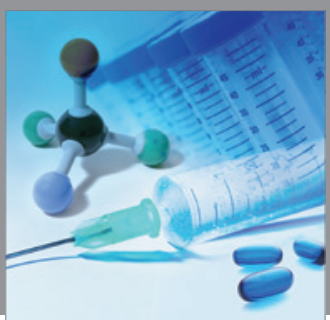

International Journal of

Medicinal Chemistry

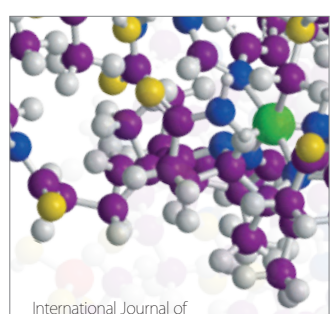

Carbohydrate Chemistry

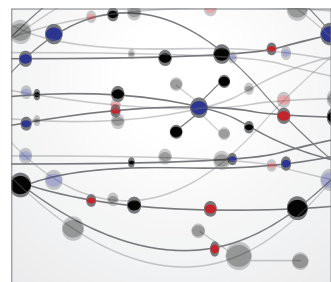

The Scientific World Journal
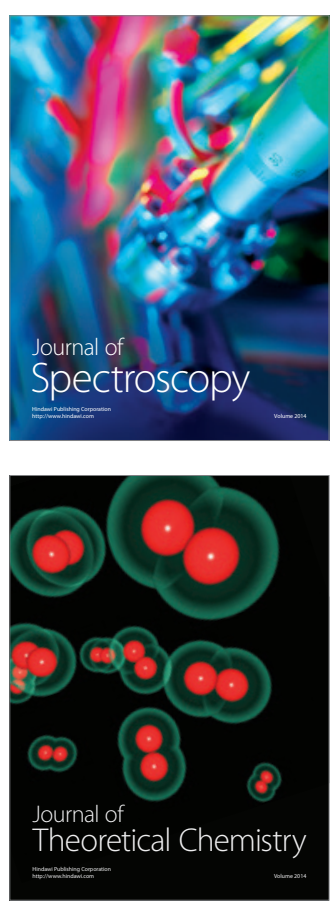
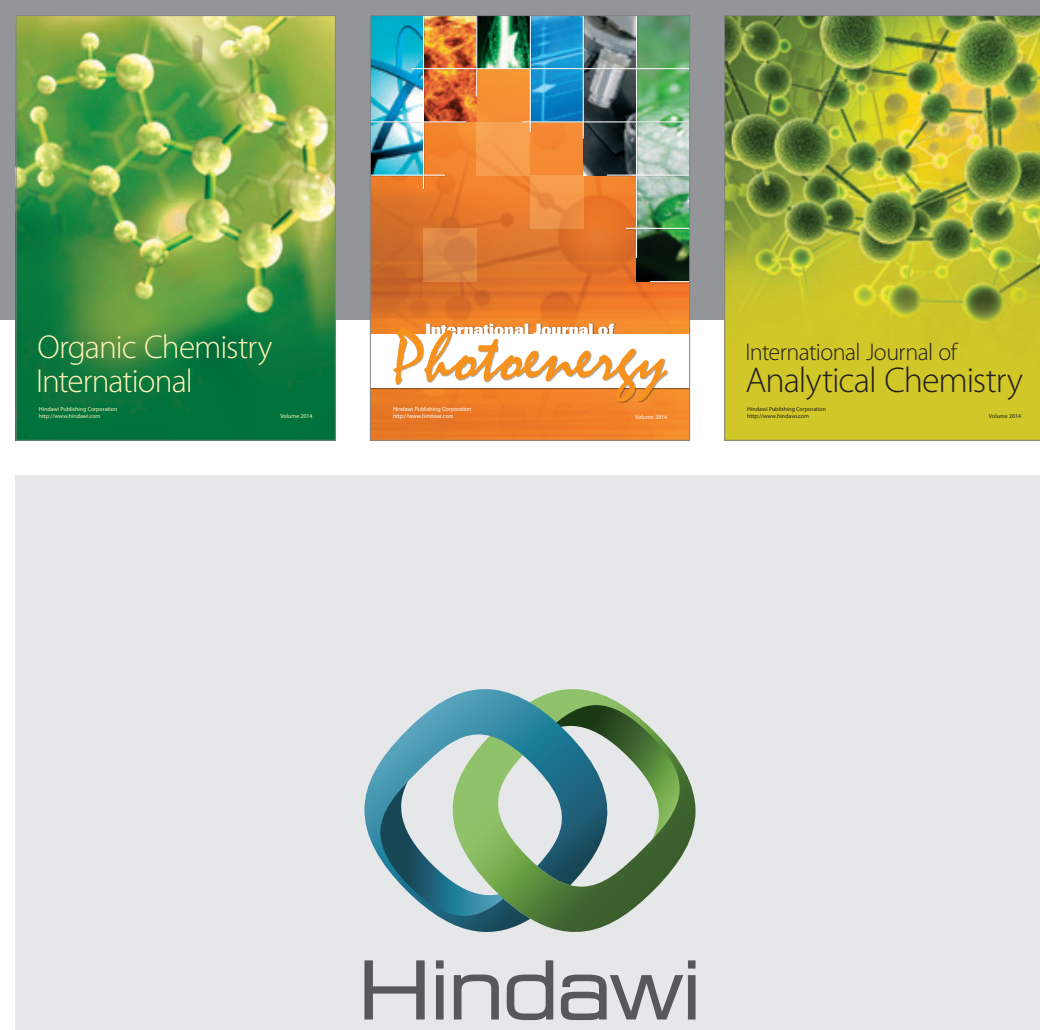

Submit your manuscripts at

http://www.hindawi.com
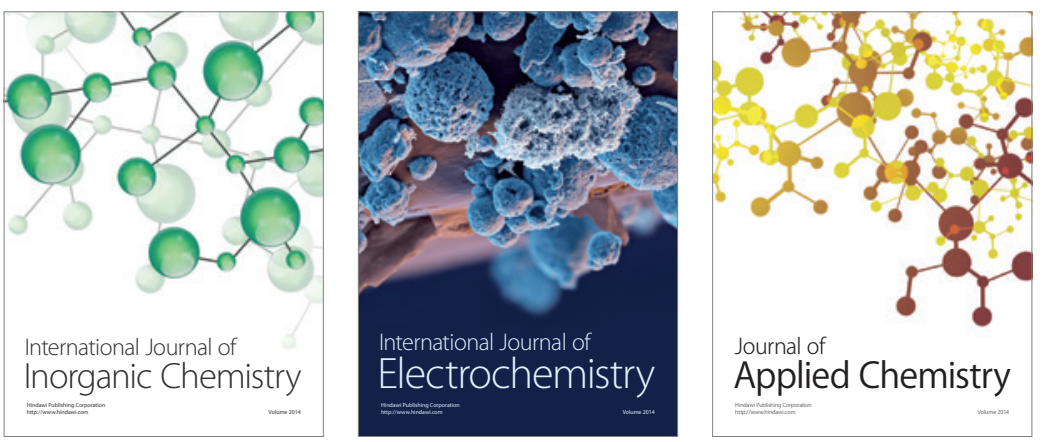

Journal of

Applied Chemistry
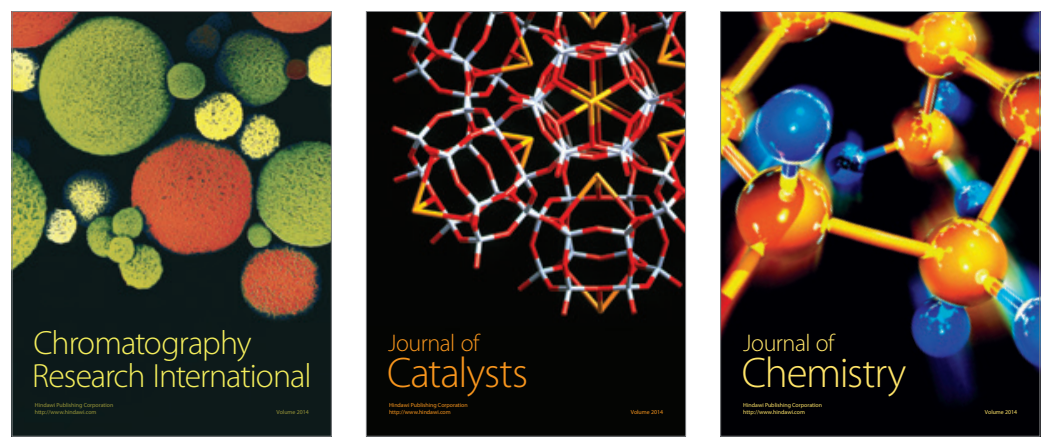
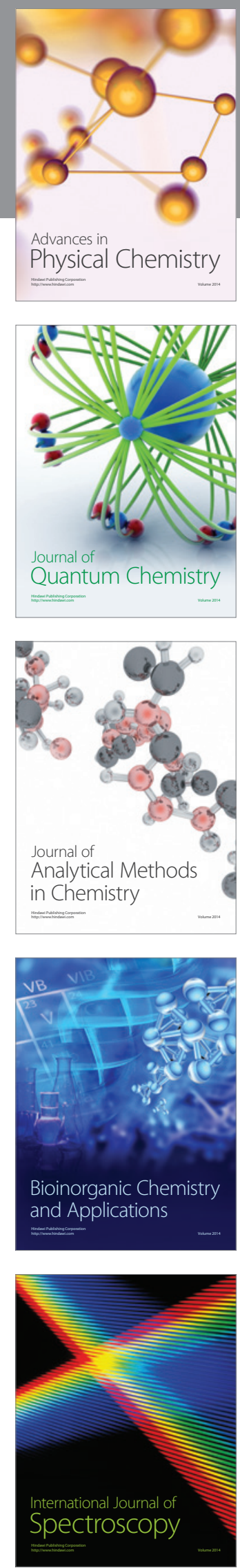